\title{
Traços ensaísticos na construção da narrativa fílmica
}

\author{
Eduardo Paschoal de Sousa*
}

Resumo: O presente artigo discute o filme-ensaio e o cinema ensaístico como métodos de elaboração da narrativa fílmica, presente mais diretamente no documentário Sertão de acrílico azul piscina (2004), de Karim Aïnouz e Marcelo Gomes, e de forma subjetiva no longa Viajo porque preciso, volto porque te amo (2009), dos mesmos diretores. Indaga, também, como essa construção tende a um entremeio narrativo, na junção de várias camadas e territórios do cinema.

Palavras-chave: filme-ensaio; cinema brasileiro; cinema ensaístico; hibridismos.

Resumen: En el presente artículo se discuten el filme-ensayo y el cine ensayístico como métodos de elaboración de la narrativa fílmica, presente más directamente en el documental Sertão de acrílico azul piscina (2004), de Karim Aïnouz y Marcelo Gomes, y de forma subjetiva en el largo Viajo porque preciso, volto porque te amo (2009), de los mismos directores. Se indaga, también, cómo esa construcción tiende a un intermedio narrativo, en la unión de varias capas y territorios del cine.

Palabras clave: filme-ensayo; cine brasileño; cine ensayístico; hibridismos.

\begin{abstract}
This article discusses the essay film and the essayist cinema as methods of elaboration of the film narrative, present more directly in the documentary Sertão de acrílico azul piscina (2004), of Karim Aïnouz and Marcelo Gomes, and of subjective form in the long Viajo porque preciso, volto porque te amo (2009), by the same directors. He also asks how this construction tends to a narrative intersection, at the junction of several layers and territories of the cinema.
\end{abstract}

Keywords: essay film; Brazilian cinema; essayist cinema; hybridity.

Résumé : Cet article traite du film-essai et le cinéma essayiste comme méthodes d'élaboration du récit cinématographique, plus directement dans le documentaire Sertão de acrílico azul piscina (2004), de Karim Aïnouz et Marcelo Gomes, et de forme subjective dans le long Viajo porque preciso, volto porque te amo (2009), des mêmes réalisateurs. Il demande également comment cette construction tend vers une intersection narrative, à la jonction de plusieurs strates et territoires du cinéma. Mots-clés : film-essai ; cinéma brésilien ; cinéma essayiste ; hybridité.

* Doutorando. Universidade de São Paulo, Escola de Comunicações e Artes, Programa de Pós-Graduação em Meios e Processos Audiovisuais, na linha de pesquisa Cultura Audiovisual e Comunicação (com bolsa Fapesp). 05508-020, São Paulo, Brasil.

E-mail: eduardopaschoals@gmail.com

Submissão do artigo: 18 de maio de 2018. Notificação de aceitação: 20 de julho de 2018 .

Doc On-line, n. 24, setembro de 2018, www.doc.ubi.pt, pp. $42-59$. 
Há uma subjetividade evidente na construção de Sertão de acrílico azul piscina (2004), de Karim Aïnouz e Marcelo Gomes. O curta documental retrata uma viagem por seis Estados do sertão nordestino, no Brasil - Pernambuco, Paraíba, Ceará, Alagoas, Sergipe e Bahia. O objetivo inicial dos realizadores era gravar as manifestações populares em feiras livres, mas sem o propósito de reverter o material capturado em contexto documental em um filme específico. A ideia era uma coleta de impressões e sensações, com caráter exploratório, conforme eles relataram a Jean-Claude Bernardet (2010).

Sertão é um filme indexado como documentário, mas essencialmente hibrido. Com uma linguagem que se aproxima do sensorial, reúne paisagens e personagens de forma indireta e livre, não como uma construção individualizada. As mulheres e os homens que são retratados pelo aparato não são distinguidos propriamente como personagens, mas compõem uma construção maior, a paisagem e as impressões de uma viagem pelo sertão, em uma narrativa carregada de subjetividade.

Não há a constituição de um narrador, nem tampouco uma voz over que direcione o espectador pela história. O que há - e quando há - são vozes fora de quadro, sem correspondência entre imagem e som, que orientam o espectador para o que está sendo retratado, muitas vezes sutilmente. A estética da imagem é próxima à do experimental, com quadros borrados, sequências com alterações na temporalidade da cena, construídas mais como um recurso poético que documental.

Depois de Sertão, foi a vez de os mesmos diretores montarem Viajo porque preciso, volto porque te amo (2009), que realiza um caminho próximo ao do curta, mas rumo à ficção. Também com uma construção inevitavelmente híbrida, o longa busca realizar a viagem pelo sertão nordestino, dessa vez sob a ótica de um personagem, o protagonista de quem só conhecemos a voz e o relato, não a imagem. O filme, composto fundamentalmente pelo material obtido na experiência anterior, em contexto documental, tenta a todo momento alterar a referencialidade das imagens em uma reapropriação ficcional, emulando essa experiência, mas na ótica de José Renato, o protagonista.

O resultado é uma obra cujos contornos do referencial e de uma experimentação nas imagens, aos mesmos moldes de Sertão, estão presentes o tempo todo. Várias das sequências montadas no curta são replicadas no longa, utilizando iguais recursos da banda sonora, mas com outro propósito: se no primeiro a ideia é que a experiência da viagem seja completada nos olhos do espectador, no segundo esse percurso é concluído no próprio personagem, em suas experiências e em uma elaboração narrativa que justifica a angústia das 
imagens, a desilusão amorosa e um certo ceticismo em relação aos sentimentos românticos que deriva dela.

A partir dessas duas obras, iremos refletir como o filme-ensaio se configura, não apenas em um gênero ou território do cinema, mas também como uma diretriz ensaística, ferramenta para a elaboração de narrativas híbridas, na junção de gêneros e campos cinematográficos. Pensamos, a partir dos dois filmes, que em Sertão de acrílico azul piscina há efetivamente uma criação próxima ao filme-ensaio, ainda que se mantenha a referencialidade documental, mas que no caso de Viajo porque preciso, volto porque te amo, esse traço está mais presente como método ensaístico que propriamente como traços de um gênero fílmico. Iremos desenvolver essa ideia pouco mais à frente.

\section{A montagem e o ensaístico}

A tensão nas narrativas de Sertão de acrílico azul piscina e de Viajo porque preciso, volto porque te amo, percebida logo nas primeiras imagens de cada filme, deve-se muito à forma como os filmes foram montados. Esse artifício de rearticular as imagens de maneira a adquirirem outros sentidos é mais contundente quando se trata de filmes de arquivo. Nesse caso, tais articulações legam ao material audiovisual, inevitavelmente, uma característica ensaística marcante, já que, além da clássica ordenação narrativa - comum tanto à ficção quanto ao documentário - abre-se uma fresta ao território do filme-ensaio, em que é profunda a presença de uma enunciação que organiza e faz escolhas perante às imagens.

Para López (2015:67), o princípio da montagem, ou seja, a ordenação do filme em um discurso e uma narrativa próprios, é mais efetivo quando se trata da remontagem dos fragmentos, do filme de arquivo. Isso porque, na visão do autor, "ao voltar a olhar uma imagem fora de contexto impõe-se uma reflexão sobre essa distância (entre o sentido original e o que adquire em seu novo contexto), podendo servir como introdução de um componente ensaístico", que também pode ter uma derivação analítica, ao se interpretar a imagem de outra forma.

Rascaroli (2009) também destaca que há uma maior propensão e, em alguns casos, uma inevitabilidade do ensaio no caso de filmes de arquivo e montagem (ou nos compilation films). Blümlinger (2013:84) vai além e caracteriza esse tipo de apropriação de imagens em filmes de arquivo como uma remontagem ensaística, que não necessariamente pode resultar em um filme-ensaio, mas que contém algumas de suas características.

O que determina a possibilidade de uma ensaística cinematográfica, para Bernardet (2004:77) é a passagem de um filme para compor outro filme, ou a 
reapropriação das imagens em contextos diferentes. Nesse caso, as imagens deslocadas conteriam o que o autor chama de resíduo da obra anterior, uma capacidade referencial diferente da documental, mais próxima a uma intertextualidade entre obras.

Em Sertão, a reapropriação, por mais que seja um procedimento de produção, parece menos evidente ao espectador, já que as imagens ali contidas continuam a ter a mesma intenção documental, ao menos na indexação proposta, e o ineditismo da primeira obra. Em Viajo, no rearranjo das imagens deslocadas de seu contexto original, em que pese sua referencialidade, fica mais evidente uma decisão de montagem na composição do filme e, portanto, uma aproximação ensaística por esse viés.

Sob outros aspectos - como a subjetividade, a liberdade de pensamento que forma a cadência narrativa e produz múltiplas camadas de sentido, a despreocupação com a narrativa linear, a não-existência de personagens individualizados, a utilização de pessoas e imagens mais como paisagens afetivas do que como fontes -, Sertão apresenta-se mais inclinado ao ensaio que Viajo.

Para compreendermos como isso se dá em uma obra e outra, é necessário começar por investigar esse território amplo, relevante e muito profícuo do filme-ensaio na produção audiovisual. Procuraremos delinear brevemente algumas ideias para a definição desse território; suas características e formas de apropriação; e como cada uma delas pode estar mais próxima ou mais distante dos nossos objetos, já que carregam em si mais traços do ensaístico que propriamente uma circunscrição ao território do filme-ensaio unicamente.

\section{O filme-ensaio como território do cinema}

As imagens se ordenam como um conjunto de impressões dos próprios realizadores, ou da enunciação, sobre a narrativa que se constrói em tela. A cadência das imagens é poética, sutil, e dá espaço para que as ideias de quem as conduz fluam de forma liberta, menos preocupada com a ordenação clássica dos assuntos que com a eficiência do efeito de pensamento. Esse tipo de cinema, mais próximo à subjetividade, à eloquência e à liberdade de pensar (Machado, 2004), é uma das características do filme-ensaio, um território amplo, mas cujas teorização e delimitação são recentes.

A própria definição e explicação do que é o ensaio fílmico permanece complexa. Corrigan (2015:8) reconhece a dificuldade nessa delimitação, mas não por ser recente, já que para o autor a existência desse tipo de produção audiovisual remonta, pelo menos, à década de 1910, nos primeiros filmes silenciosos. Para ele, a própria dificuldade em se delimitar e circunscrever o ensaio em alguns tipos específicos de filme é o que o torna tão inventivo: 
A meio caminho da ficção e da não ficção, das reportagens jornalísticas e da autobiografia confessional, dos documentários e do cinema experimental, eles são, primeiro, práticas que desfazem e refazem a forma cinematográfica, perspectivas visuais, geografias públicas, organizações temporais e noções de verdade e juízo na complexidade da experiência. (Corrigan, 2015:9).

É do filme-ensaio a tarefa de levantar novas questões sobre a construção do sujeito, a relação dele com o mundo e a potencialização das possibilidades estéticas do cinema, a partir de sua caracterização perdida, fragmentada, descontraída e até irônica do mundo, segundo Papazian e Eades (2016:1). Já que a delimitação de uma única classificação para o ensaio seria incorreta, Rascaroli (2009:1) sugere situá-lo na intersecção entre documentário, filme de arte e prática de vanguarda, além de ser correto dizer que se trata de obras subjetivas e geralmente em primeira pessoa. Dessas marcas, há duas características primordiais para se considerar um filme mais próximo desse território, segundo a autora (idem:32): a reflexividade e a subjetividade, que requer essencialmente a construção de um espectador que compreenda suas dinâmicas internas e esteja ciente das múltiplas ferramentas do ensaio para atrair sua atenção e comprovar o ponto de vista do enunciador.

É essa liberdade de invenção proveniente da subjetividade e do traço em primeira pessoa que, para Stam (2015:123), possibilita a exploração estética do ensaio com um caráter digressivo, questionador, no qual as preocupações que seriam periféricas ao tópico principal da narrativa - características mais fenomenológicas que pragmáticas - assumem o primeiro plano do filme, são levadas ao centro do quadro.

Por tratar, na maior parte das vezes, de questionamentos sobre o mundo e colocá-lo à prova do ponto de vista da não-ficção, o filme-ensaio foi associado muito cedo ao documentário, conforme postula Xavier (2015:226), mas também é visto como um derivado do cinema experimental e de algumas experiências inventivas do campo ficcional:

O melhor, no entanto, é pensá-lo como superação dessas fronteiras, como invenção que abriu um continente de indagações geradas no confronto entre o cinema e a filosofia. A ideia do filme como pensamento em ato (...) teve certamente seu efeito no uso mais específico, mediado pela história da filosofia, da noção de ensaio referida aos filmes, um uso cada vez mais frequente na crítica, seja na lida com o novo cinema (e o novo vídeo), seja na análise de obras do cinema moderno, antes trabalhadas a partir de noções como cinema poético, desconstrutivo, experimental ou conceitual. (Xavier, 2015:226).

Ao indexar um filme como ensaio, na visão do autor, já se espera uma experiência intelectual mais aberta, sem a exatidão da narrativa linear, um impulso antissistêmico e com foco na transitoriedade como a área de maior atenção para a obra, ou seja, uma marca de subjetividade inerente ao filme. 
O espaço de interpretação deve ser, nesse sentido, sempre o do entre. López (2015:57) salienta a condição híbrida do ensaio e, portanto, do ensaístico; uma confluência de vários territórios e gêneros, a começar pelo cinema documentário e experimental. A intersecção ocorre, em primeira instância, porque apesar da referencialidade do ensaio, ele não se propõe a filmar e organizar o mundo, conforme o documentário, mas sim constituí-lo. Isso quer dizer que a preocupação está mais em construir um novo mundo, sob os olhos de quem o experienciou, do que retratar as coisas do mundo como elas são. Há, para ele (idem:86), uma subordinação do vínculo indicial, ou a relação com o mundo real e histórico, ao subjetivo, uma forma de olhar as imagens mais como evocação do que representação.

É importante observar como o filme-ensaio, de modo geral e a partir das características estabelecidas pelos autores citados, se aproxima do modo poético do documentário, elaborado por Nichols (2005:138) como uma das inúmeras distinções que sugeriu dentro do território documental. Segundo ele, há uma ênfase mais no estado de ânimo do realizador, no tom e no afeto, que no objetivo de demonstrar conhecimentos ou realizar ações de persuasão.

O autor elabora que esse modo poético "sacrifica as convenções da montagem em continuidade, e a ideia de localização muito específica no tempo e no espaço derivado dela" e ainda que retire do mundo histórico a matéria-prima para sua narrativa, ele a transforma de maneira diferente, "ao representar a realidade em uma série de fragmentos, impressões subjetivas, atos incoerentes e associações vagas" (idem:140). Para Rascaroli (2009:37), o que faz com que o ensaio seja mais contundente em experimentação do que o documentário é a sucessiva presença e ausência de um enunciador, um constante movimento de expor suas impressões sobre o mundo e apagar-se; de movimentar a visão do espectador para entender o filme como um produto da mente do realizador, mas se colocar alheio a ele, de forma menos individual e mais generalista.

Esse pode ser um dos principais aspectos que diferencia o ensaio fílmico do modo poético de documentário, além da falta de pretensão em persuadir o espectador pela experiência, por parte do documentário, mas sim pela própria argumentação da obra ao defender um ponto; é como se o filme-ensaio conduzisse uma experiência que prove o ponto que defende, enquanto o documentário se utilizasse de inúmeros argumentos práticos para também o fazer. De uma forma ou de outra, é mais importante compreendermos as características do ensaio fílmico como um campo e um território híbridos - que abarca as diversas outras categorizações do cinema -, do que contorná-lo e restringi-lo a manifestações específicas e delimitadas. Analogamente, a tentativa de restringir os campos seria contraditória com o próprio princípio do ensaístico. 
A partir dessas primeiras definições, pensamos que há duas formas de aproximação dos objetos deste artigo à vertente ensaística. A primeira delas é a forte ligação que Sertão de acrílico azul piscina apresenta com o filme-ensaio como território do cinema, por se tratar de um documentário experimental, subjetivo, poético, de experimento estético e narrativo. Ainda assim, há alguns traços do documental e do experimental que o distanciam de ser classificado como filme-ensaio puramente - sem considerar o fato de que sua própria indexação, como documentário, não permite tal definição prática. Por isso, consideramos esse um filme essencialmente híbrido, cujas camadas narrativas se sobrepõem e se tensionam; e sem dúvida uma delas é a do filme-ensaio.

Por outro lado, há o longa Viajo porque preciso, volto porque te amo, que não consideramos próximo do filme-ensaio por ser mais identificado com a esfera ficcional narrativa e por trazer um narrador ficcional que quebra a regra da enunciação intelectual do filme-ensaio. No entanto, há em Viajo o ensaístico como método de construção da obra, que se explica pela ordenação consciente de planos, a reorganização da narrativa sob um tom ficcional, a presença de um discurso do realizador que monta o filme dessa forma, além do fato de ser uma obra construída fundamentalmente na montagem.

\section{Sertão e a proximidade com o filme-ensaio}

A cena anterior é de uma profusão de fieis em meio a uma igreja e uma feira, onde aparentemente o movimento é grande. São caminhões, carros e ônibus que transitam em frente à câmera e que levam multidões à peregrinação por Padre Cícero, cujo monumento foi exibido sequências antes. Não há nenhuma indicação explícita de lugar ou qualquer referência que leve a crer que se trata de uma feira religiosa, apenas sugestões em um caleidoscópio de imagens conectadas.

Alguns quadros depois e já é noite, aos dez minutos de Sertão de acrílico azul piscina (figura 1). O som é direto, com buzinas e freadas de caminhões. Há vários letreiros luminosos que se alternam na imagem, um plano aberto de dentro de um carro que, aparentemente, circula pelas ruas bem mais vazias que anteriormente. Os escritos estão desfocados, e não parece necessário que sejam lidos. Há vozes vindas de longe, sem identificação. O que ouvimos são palavras soltas, uma ou outra, que não formam frases inteligíveis. Mais uma vez, esse não parece ser o objetivo. Começa então uma música instrumental melancólica que toma toda a banda sonora, enquanto os letreiros continuam a aparecer.

O desfoque da imagem aumenta, de modo que as luzes borram as imagens e os faróis de freio dos carros e motos são apenas grandes traços avermelhados 
no centro da tela. Há trovões, barulho de vento, e a combinação desses ruídos com a música aumenta a dramaticidade e a melancolia. A angústia fica presa na tela e começa a contaminar o espectador. A câmera gira 90 graus, e as imagens passam a entrar do alto da tela para baixo, aumentando a sensação de tontura, retratando um enunciador perdido em meio à noite que borra a tela com suas cores vibrantemente mórbidas.

Os riscos e os letreiros desaparecem em um fade, bem como a música instrumental, para dar lugar a um forró, ainda no quadro preto: Forró em Campina, de Jackson do Pandeiro, executado por algum grupo. A cena que se segue, então, é a de duas mulheres vestindo bermudas e tops, dançando juntas, mas um pouco distantes, em uma casa simples, com um pé direito amplo em uma grande sala, enquanto músicos de uma banda tocam o forró ao fundo. A música, agora, é aparentemente diegética, e elas seguem o ritmo. O enquadramento permite que apenas uma delas apareça em tela; a outra tem a cabeça fora de quadro e aparece aos poucos, até entrar no enquadramento, conforme dança.

Um corte e a música continua, mas dessa vez quem aparece são um homem e uma mulher, dançando bem próximos. Ela sorri tímida para a tela e ele tenta levantá-la no ritmo da música, pressionando fortemente sua cintura. Outro corte e ao fundo continuam as duas mulheres do início, enquanto em primeiro plano estão um homem, uma mulher e, junto deles, aninhado ao casal que dança, a fragilidade de um bebê muito pequeno, com um macacão branco. $\mathrm{O}$ homem dança mais lento e se preocupa em segurar a cabeça do bebê em seu braço. Seus olhos estão fixos na câmera e os da mulher alternam entre a lente e a criança. A sensação é a de que há um cuidado absoluto com a fragilidade do pequeno, mesmo em meio à agitação do forró.

Corte. Novamente as duas mulheres do início dançam na pista, mas dessa vez apenas suas cinturas e quadris são visíveis em tela. Elas dão lugar ao grupo que toca - agora Chiclete com Banana, também de Jackson do Pandeiro. A imagem é granulada e desfocada. O enquadramento se expande e o que vemos é o salão com vários casais dançando, todos ao mesmo tempo. Uma música melancólica e instrumental, a mesma utilizada na sequência dos luminosos, passa a dividir o som com o forró, até que cresce e se torna a única música do filme.

A imagem desacelera. A dança fica cada vez mais lenta. A mulher com o bebê está agora apenas com ele, sorrindo para a tela e para a criança, alternadamente. Corte. Um still enfoca o letreiro que estava atrás dos músicos, e não era possível de se ler até então: SOLIDÃO NN é o que está escrito. Um conjunto de fotografias surgem na tela, uma a uma: as mulheres com bermuda 
e top junto dos músicos; um casal dançando em primeiro plano; uma sequência reconstitui o vídeo do início; as duas mulheres olham fixamente para a tela enquanto dançam. Tudo isso com a mesma música de fundo, como se quisesse retratar a própria melancolia e solidão que dá nome ao lugar: SOLIDÃO NN.

A sucessão dessas imagens é aberta a muitas interpretações. A julgar pela sugestão do letreiro, podemos pensar que se trata da persistência da solidão, da melancolia. Há um enunciador, cujos olhos veem as mesmas imagens que os nossos, que estava em um ambiente de intenso movimento durante o dia. Quando a noite chega, com os luminosos entorpecedores, ele tem tonturas e se sente profundamente angustiado. Vai buscar em um clube de forró uma alternativa para sua solidão e tenta se animar. A imagem da fragilidade de um bebê nos colos de seus pais, duas mulheres que dançam separadas, um casal que força uma aproximação na pista. Tudo compõe uma cena ainda melancólica e sentimental, reforçando e transparecendo pela música os mesmos sentimentos do início, a mesma angústia que não é resolvida com a multidão, nem com os acordes animados do forró. 

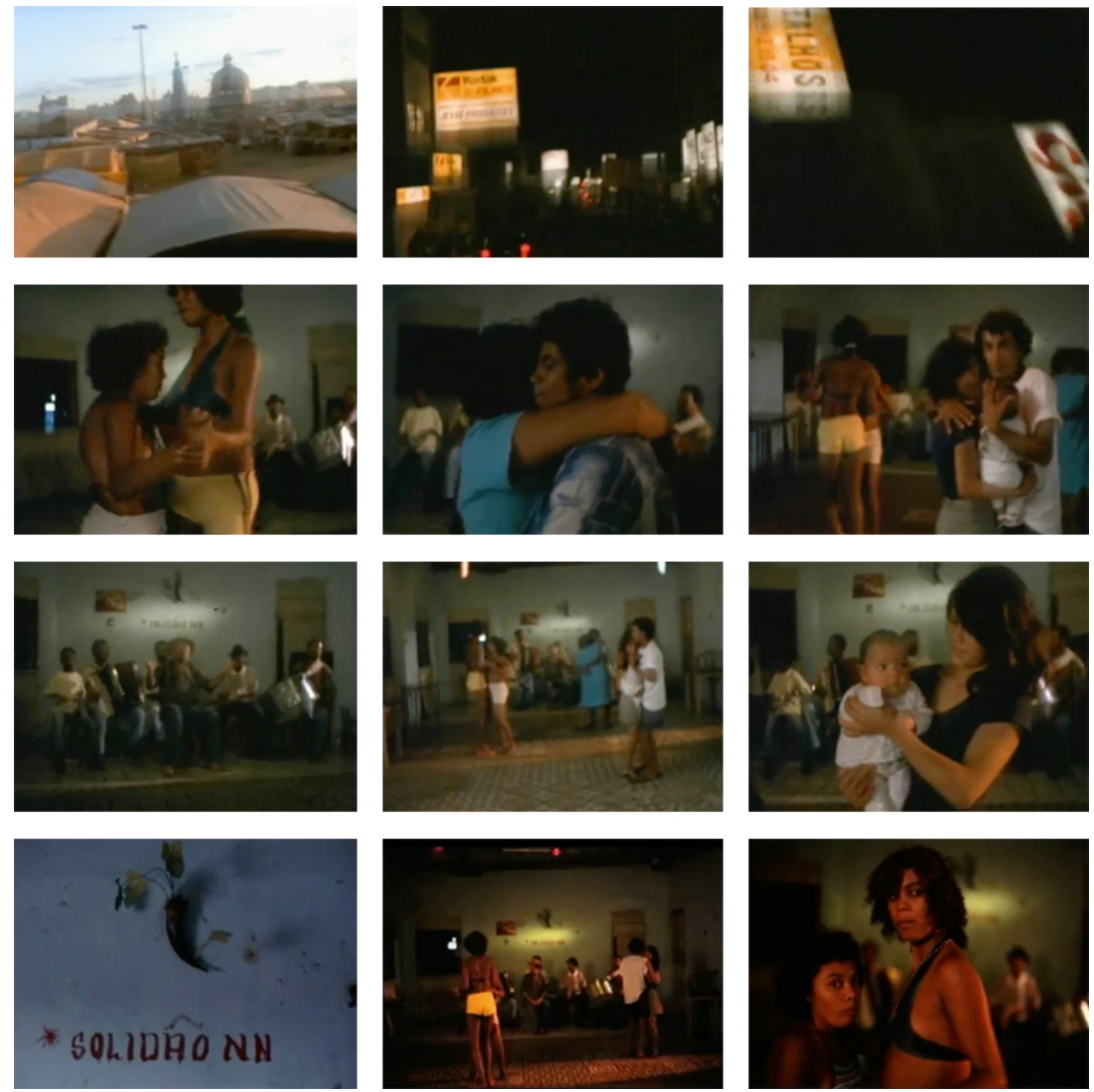

Figura 1. Sequência em Sertão; a feira na romaria, os letreiros distorcidos e o baile de forró.

Fonte: frames obtidos por este autor a partir do DVD da obra.

O contraste entre o exterior e a cena do baile se dá na própria diegese fílmica, na utilização de música não presente em cena para sugerir os sentimentos e pensamentos internos de quem está fora de quadro, um enunciador que não vemos, que não se constitui senão pela montagem, que nos transmite suas sensações apenas por sugestão, pela cadência das músicas e pela sutileza de letreiros. Essas mensagens, quase codificadas de uma ordenação fílmica que nos induz à subjetividade da cena, se aproximam de um filme-ensaio, de uma construção narrativa ensaística cujo enunciador está presente mesmo em uma ausência - de narrador, de indícios textuais, de evidências imagéticas.

Para Rascaroli (2009:33), em um nível de comprometimento textual, um ensaio é a expressão de uma reflexão pessoal e crítica. Ela não se propõe como anônima ou coletiva, mas originária de uma única voz autoral. Esse enuncia- 
dor, para a autora, é corporificado em um narrador, que é muito próximo do autor real, extratextual. Por mais que isso não ocorra de forma evidente em Sertão - não temos um narrador em voz, ou em personagem, que se faz presente -, há uma sugestão de narração na sequência das imagens e das músicas que conduz àquela autoria.

A ausência dessa estrutura de narração é, para Corrigan (2015:21), um traço do ensaístico, mais que do filme-ensaio. Para ele, além do privilégio na expressão e na subjetividade pessoal, o que determina um traço do ensaismo no cinema é "essa própria noção de expressividade e sua relação com a experiência", algo fundamental para esse campo. O autor também aponta para a fragmentação de um $e u$, repensado e refeito na expressão ensaística como modo representacional narrativo. Não há, para ele, uma subjetividade autorizada nesses casos, apesar de todas as práticas dramáticas problematizarem encontros entre o eu e o mundo, mas "a dinâmica e o equilíbrio desse encontro (...) parecem se diferenciar significativamente no ensaístico, como um tipo de fragmentação que perturba de forma dramática a subjetividade e a representação" (idem:23).

Apesar de não se individualizar como narrador, o enunciador do curta está mais próximo a um enunciador ensaístico que documental. Na definição de Rascaroli (2009:34), diferentemente do documentário tradicional, cuja visão do enunciador representa uma consideração social e coletiva, no caso do ensaio ela é estruturada como uma escolha pelo pessoal e individual, pelo relato de uma experiência particular que não é representativa do todo, mas sim daquela situação, menos como fenômeno e mais como memória.

Essas representações subjetivas fazem com que o enunciador perca a autoridade generalista própria ao documentário, segundo Corrigan (2015:35). A forma do filme-ensaio cede esse eu histórico a acontecimentos, ações e objetos que são sobrepostos e mais importantes em suas vivências subjetivas que em acontecimentos referenciais:

A subjetividade ensaística - em contraposição a muitas definições do ensaio e do filme-ensaio - refere-se, então, não simplesmente à colocação ou ao posicionamento de uma consciência individual diante e dentro da experiência, mas a uma consciência ativa e assertiva que se testa, desfaz ou recria por meio da experiência, incluindo as experiências da memória, do argumento, do desejo ativo e do pensamento reflexivo. (Corrigan, 2015:34).

Há uma versão do mundo histórico presente no ensaio, mas não como um lugar existente e habitável, simbólico de uma realidade passível de ser testada, mas que se configura a partir de uma releitura conceitual, fenomenológica, um $e u$ que encontra e experimenta esse local para narrá-lo ao espectador. Na sequência de Sertão, mais que se concentrar em documentar um baile de forró 
em uma cidade do interior do nordeste brasileiro, os realizadores optam por transmiti-la como uma experiência. Um baile que poderia soar alegre, folclórico e catártico frente a todas as outras experiências de vida foi substituído por uma sequência que transborda melancolia e a angústia da solidão em meio a muitas pessoas. Na fragilidade de um casal que tenta equilibrar o filho ainda bebê no meio do forró, há também a demonstração da vulnerabilidade, tomando a forma de uma construção emotiva, subjetiva e intelectual em que as imagens dizem mais que suas representações.

Sobre o endereçamento da imagem a seu espectador, há no ensaio, para Corrigan (2015:34), uma estrutura que direciona um discurso a um você pressuposto, que é "descorporificado e despersonalizado", mas que ainda assim se torna presente nas intenções do enunciador. Esse diálogo, segundo Rascaroli (2009:35), é diferente do documentário clássico, pois interpela constantemente cada espectador como um indivíduo e não um membro de uma audiência coletiva e anônima - o que seria mais comum ao documental. Para a autora, cada um na plateia é convidado a se engajar em uma relação dialógica com o enunciador, a fim de que seu contato se torne ativo, interagindo intelectual e emocionalmente com a narrativa.

Essas considerações fazem sentido em Sertão pela forma como cada espectador pode compor sua experiência, por meio de uma estrutura textual mais aberta e subjetiva, que não dá direcionamentos textuais explícitos, mas apenas sugere os caminhos possíveis de se trilhar. O hibridismo estético no campo da imagem, com a utilização de fotografias e stills que irrompem do filme para dar lugar à retomada da experiência por meio da memória visual - na cena do baile de forró, há a recapitulação dos acontecimentos em fotografia, uma espécie de redundância de roteiro -, amplia as fronteiras do gênero documental, ensaístico, experimental, e utiliza de todas as potencialidades, inclusive estéticas, para narrar um conjunto de impressões e, mais que isso, criar um mundo possível de ser experimentado pelo espectador; um convite para dividir com o enunciador uma cadência narrativa, recriando sua própria, em uma estrutura aberta, ampla e individual.

\section{Viajo e o ensaístico como método}

No filme Viajo porque preciso, volto porque te amo, a mesma sequência citada no item anterior é remontada de outra maneira. Mudam as imagens que a antecede e as imagens que a sucede, em uma outra cadência narrativa, em que há, ainda, um narrador-personagem com suas próprias opiniões sobre os acontecimentos. O que vemos nas imagens é o que ele também vê e as impressões que temos são as que ele nos narra. Isso altera o sentido das imagens 
como ensaio, porque a significação que obtemos delas já está determinada pela diegese e pela estrutura ficcional. É a ficção que determina as impressões do espectador, não mais uma abertura estrutural ampla para que haja a composição de significado individual sobre a cena. Vejamos como isso se desenrola na obra.

A cena anterior é a de Patrícia, uma personagem apresentada por José Renato. Ele é personagem principal da ficção, geólogo que sai em uma viagem pelos mesmos seis Estados do nordeste brasileiro a fim de analisar a viabilidade de construção de um canal de águas, ligando uma parte a outra. Já Patrícia, pelo que sabemos a partir do protagonista, é uma dançarina e faz programas nas horas vagas. A câmera a filma em frente a uma banca vazia de feira, posando para aqueles que passam, insinuando-se, segundo o que o narrador nos contou, para conseguir clientes. Ele diz ter passado o dia todo com ela e, pela primeira vez, ter conseguido esquecer sua desilusão amorosa por um tempo. Um corte e Patrícia senta-se diante da câmera, em frente a uma banca de frutas da feira local, e responde a um interrogatório, se apresenta explicando onde trabalha, o que faz da vida, seus sonhos e projetos futuros (figura 2). $\mathrm{O}$ personagem que a interroga é o narrador, extraindo dela o que quer que saibamos sobre sua história. Essa cena dura pouco mais de três minutos, até que há um corte e entramos na mesma sequência do baile de forró, exatamente como retratada em Sertão.

A música, aparentemente diegética, tocada pelo grupo de músicos ao fundo, é outra nesta obra: antes Forró em Campina, em Sertão, e agora Forró na Gafieira, ainda de Jackson do Pandeiro. A música divide a banda sonora, por vezes, com o barulho de conversas e vozes que se intercalam, como se a casa estivesse pouco mais cheia do que as imagens mostram. A cadência também é mais rápida que no curta documental, apesar de a sequência dos personagens ser exatamente a mesma - duas mulheres que dançam de bermuda e top sem mostrar seu rosto; um casal em movimentos bem colados, até que a mulher olha tímida para a câmera; outro casal que segura delicadamente seu bebê, e a mãe que fica sozinha com ele em quadro.

A música diegética não se altera, mas abaixa gradativamente, na medida em que dá lugar a fotos em tela, retratando a mesma sequência de Sertão, e divide espaço com conversas ao fundo. Percebemos agora, quando há um close em uma das mulheres que dançavam juntas no início da sequência, que se tratava de Patrícia, já apresentada anteriormente para nós, espectadores. É Patrícia quem dança no forró e a memória que temos dela nos faz individualizála como personagem. Depois dela, o mesmo letreiro que aparece na outra obra: SOLIDÃO NN. 
Há um corte, a música instrumental aumenta e começa a sequência de letreiros desfocados, com luzes que se embaralham na tela. O som de motos e carros vai dividindo a banda sonora com a música instrumental e a voz de uma mulher, aparentemente funcionária da rodoviária, que anuncia um ônibus partindo em direção a Fortaleza. Todos esses sons diminuem, para dar lugar a José Renato: "Sinto amores e ódios repentinos por você. Viajo porque preciso. Não volto, porque ainda te amo". Quando termina a frase, enquanto as imagens ainda apresentam o percurso por uma cidade com seus letreiros luminosos à noite, a mesma voz da funcionária da companhia de ônibus finaliza: "Desejamos a todos uma boa viagem". Há um corte antes de começar o que seria a sequência dos luminosos virados em 90 graus, que ocorre em Sertão, mas não em Viajo. 

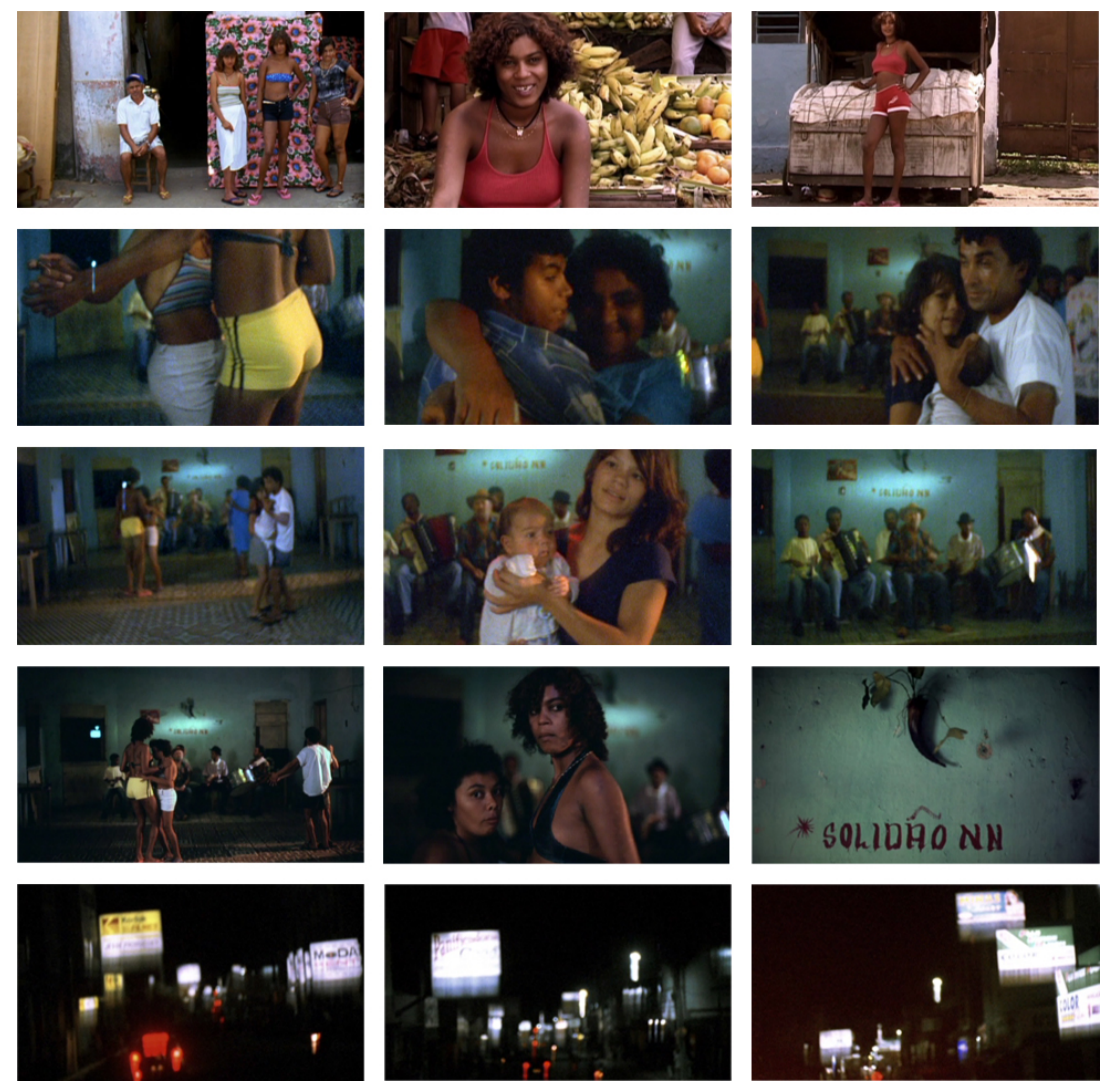

Figura 2. Quase a mesma sequência em Viajo, mas com início e fim diferentes; a forma da montagem na narrativa ficcional, comparada com o documentário, altera o sentido das imagens e cria outra relação com o espectador.

Fonte: frames obtidos por este autor a partir do DVD da obra.

A condução ficcional da narrativa, com a construção de um personagem direcionando suas emoções e sentimentos, inibe a aproximação de Viajo do filme-ensaio e o conecta mais com o cinema experimental, ao menos pela sua variação estética, pelas imagens granuladas, pelos grandes silêncios e a utilização de música instrumental de tom melancólico, transpondo ao som e às imagens as sensações do personagem. Diferentemente de Sertão, que convida o espectador a vivenciar todas as sensações com o enunciador, em Viajo a enunciação é feita pelo próprio personagem, que também nos convida a participar, mas então apenas de sua vida, sem uma criação e uma vivência autorais da experiência. 
Ainda assim, é possível identificar no longa ficcional alguns traços do ensaismo como método, seja pela ordenação das imagens e dos sons a fim de criar uma atmosfera subjetiva, seja pela remontagem e readequação das imagens em uma cadência ficcional, diegética, com a criação de um mundo da ficção, mas que carrega a referencialidade do mundo histórico.

Para Corrigan (2015:33), há casos em que o filme-ensaio é moldado pela presença de uma voz ordenadora, seja real ou ficcional, que direciona o filme para buscas e questionamentos particulares, uma presença subjetiva e uma posição enunciativa que determina o percurso narrativo a ser trilhado pelo espectador. Ainda que isso não ocorra, segundo o autor, o "ato de enunciação também pode ser assinalado de várias maneiras formais ou técnicas, entre elas a montagem e outras manipulações representacionais da imagem", que é o que vemos ocorrer em Viajo. O que nos leva a atribuir mais uma característica ensaística do que uma aproximação ao território do ensaio é que essa formação é criada a partir de um personagem ficcional, com uma vivência fictícia e com questionamentos irreais, uma desilusão amorosa e uma busca de redenção pessoal que não acontece senão no enredo do filme.

O ensaístico pode ser visto, por vezes, como um modo anterior ao próprio ensaio, como afirmam Papazian e Eades (2016:3), uma ferramenta que pode emergir de todo tipo de filme, seja ficcional ou não, que desestabiliza as convenções de gêneros, modos e estilos, e borra as fronteiras dos territórios cinematográficos. Esse procedimento pode não conter, efetivamente, um ensaio, mas traz à tona questões como a presença documental, a expressão pessoal do realizador na obra, o filme como experimento e experiência, a construção de uma utopia e uma impossibilidade a partir de um personagem.

Corrigan (2015:10) concorda que o ensaístico, como procedimento fílmico, pode ocorrer em diferentes materiais e formas artísticas, muito além do filme-ensaio, e executa uma apresentação do eu como performance, uma espécie de transcendência das estruturas narrativas que se aproxima do experimental, um processo de pensamento do realizador que contamina o filme, uma prática "que renegocia pressupostos a respeito da objetividade documentária, da epistemologia narrativa e da expressividade autoral".

Como filmes híbridos que são, cada um com suas peculiaridades, é esperado que Sertão e Viajo se aproximem e se distanciem de territórios e ferramentas da linguagem audiovisual. Por construir uma subjetividade e manter um enunciador documental muito próximo ao espectador, permitindo a elaboração de uma experiência própria a partir de uma trama aberta, o curta indexado como documentário revela traços significativos do filme-ensaio e de um cinema próximo à arte, à subjetividade, à poética. Viajo, por outro lado, se 
aproxima do ensaístico ao trazer a poesia de seu enredo na figura de um personagem principal ficcional, que também experiencia diversas situações e nos convida a vivê-las com ele, compartilhando suas memórias e sua história, mas se distancia do filme-ensaio ao fazê-lo a partir da ficção, com um roteiro mais restrito às sensações e percepções do próprio personagem, sem a individualização do espectador, conduzindo-o a uma experiência já formatada e ordenada na diegese ficcional.

De uma forma ou de outra, é inevitável pensarmos que a estratégia de montagem, aliada à origem dos filmes como filmes de arquivo, composta ora de maneira ensaística documental, ora se aproximando de uma obra experimental na ficção, elabora obras híbridas, formadas por várias e complexas camadas narrativas, que se manifestam de diferentes maneiras em um filme e outro, mas que estão ali sobrepostas e alinhadas. Acreditamos só ser possível compreender Sertão e Viajo como obras com essas múltiplas camadas narrativas, em que a delimitação de gênero ou território seria imprecisa, redutora (cf. Sousa, 2017).

Essas camadas se sobrepõem e se entrelaçam, em um emaranhado de sequências em que uma ou outra se destaca, alternadamente, mas em que todas convivem. É como se pudéssemos identificar, na tessitura narrativa dos dois objetos aqui analisados, uma complexa rede com fios de múltiplas origens e procedências, que ao se unirem não são mais elementos puros, ancorados em um gênero, em um campo, ou com um enquadramento preciso de sua origem. Da mesma forma, por mais que constituam uma nova trama, conservam em si características originárias de suas essências, o que processa, ao nosso ver, um entremeio narrativo, formado a partir do deslizamento temporal do filme, no ordenamento de suas sequências, mas também na profundidade e na profusão das imagens em tela, como se em cada quadro houvesse uma profundidade de campo, um amálgama de diversos territórios do cinema em uma única narrativa, que não permite que sejam entendidos senão por meio de suas intersecções.

\section{Referências bibliográficas}

Bernardet, J. C. (2004). A migração das imagens. In F. E. Teixeira (org.), Documentário no Brasil: tradição e transformação. São Paulo: Summus Editorial.

Bernardet, J. C. (2010). Entrevista Marcelo Gomes e Karim Ainouz. Disponível em: http://jcbernardet.blog.uol.com.br/arch2010-05-02_2010-05-08. html 
Blümlinger, C. (2013). Cinéma de seconde main: esthétique du remploi dans l'art du film et des nouveaux médias. Paris: Klincksieck.

Corrigan, T. (2015). O filme-ensaio: desde Montaigne e depois de Maker. Campinas: Papirus.

López, A. W. (2015). Um conceito fugidio. Notas sobre o filme-ensaio. In F. E Teixeira (org.), O ensaio no cinema: formação de um quarto domínio das imagens na cultura audiovisual contemporânea. São Paulo: Hucitec.

Machado, A. (2003). O filme-ensaio. Revista Concinnitas, Ano 4, 5.

Nichols, B. (2005). Introdução ao documentário. Campinas: Papirus.

Papazian, E. \& Eades, C. (2016). The essay film: dialogue, politica, utopia. Londres: Wallflower Press.

Rascaroli, L. (2009). The personal camera: subjective cinema and the essay film. Londres: Wallflower Press.

Sousa, E. P. (2017). A construção de um entremeio narrativo e a leitura hibridizante em Viajo porque preciso, volto porque te amo e Sertão de acrílico azul piscina. Dissertação de Mestrado em Meios e Processos Audiovisuais, Escola de Comunicações e Artes, Universidade de São Paulo, São Paulo.

Stam, R. (2015). Do filme-ensaio ao mockumentary. In F. E. Teixeira (org.), O Ensaio no Cinema: formação de um quarto domínio das imagens na cultura audiovisual contemporânea. São Paulo: Hucitec.

Xavier, I. (2015). A teatralidade como vetor do ensaio fílmico no documentário brasileiro contemporâneo. In F. E. Teixeira (org.), $O$ Ensaio no $C i$ nema: formação de um quarto domínio das imagens na cultura audiovisual contemporânea. São Paulo: Hucitec.

\section{Filmografia}

Sertão de acrílico azul piscina (2004), de Karim Aïnouz e Marcelo Gomes.

Viajo porque preciso, volto porque te amo (2009), de Karim Aïnouz e Marcelo Gomes. 